\title{
Market Dynamics in the EU, NAFTA, North East Asia and ASEAN: the Method of Constant Market Shares (CMS) Analysis
}

\author{
Tri Widodo \\ Gadjah Mada University
}

\begin{abstract}
One of the main aims of the regionalism and economic integration is to encourage export performance, especially intra-regional trade. The Constant Market Shares (CMS) method is commonly to examine empirically the countries' export performance. This paper is addressed to examine the regions' export performance by applying the CMS method. Firstly, this paper presents the developments of the method. Combining versions of the method by Leamer and Stern (1970), Richardson (1971a, 1971b) and Fagerberg and Sollie (1987), this paper comes up with another version of the method which, the competitive effect is explicitly extended. Second, the new version is then applied to analyze the dynamic markets of some regions (the EU, NAFTA, North East Asia and ASEAN) for the period 1980-2006. This paper concludes that the proliferation of regionalism and economic integrations in the beginning 1990-s caused the change in trade pattern. However, the change in trade pattern only happened in the short term.
\end{abstract}

- JEL Classification: F14, F15.

- Key Words: Constant Market Shares (CMS), Commodity and Market Adaptation Effects

\footnotetext{
*Corresponding address: Faculty of Economics and Business Faculty of Economics and Business, Gadjah Mada University, Jl. Humaniora 1, Bulaksumur, Yogyakarta 55281. E-mail address: ui55t003@pcnet. hue.ac.jp; kociwid@yahoo.com.

○2010-Center for International Economics, Sejong Institution, Sejong University, All Rights Reserved.
} 


\section{Introduction}

Export performance of a country changes dynamically. Theoretically, it can be explained by the demand and supply sides. The demand side is closely related to the economic development of the country's exports destinations or markets (Leamer and Stern, 1970). For example if the income per capita and the number of population in the markets increase, hopefully, the country's exports will consequently also increase. Meanwhile, the supply side is closely related to how the country could compete with other sources of supply. The country's relative factor endowments including natural resources, capital, human resources, infrastructures and technology create its comparative as well as competitive advantages.

There have been drastic changes in the world exports due to the world trade liberalization that is believed to bring more conducive and competitive world trade environments. Regionalization, economic integration, bilateral and multilateral trade agreements have significantly affected the world trade through trade creation and trade diversion. The patterns of world exports have also changed due to the dynamics in countries' specialization (Krugman, 1995; Aiginger, 1999; Wörz, 2005). In the case of East Asia, until the late 1980s these patterns were dominated by the traditional comparative advantage, which gives more emphasis on factors endowments and technology. Japan and Asian New Industrializing Economies (ANIEs) have comparative advantage in capital and human-capital intensive commodities, meanwhile the developing countries in East Asia specialized in resource-intensive and labor-intensive ones. The pattern of industrial location and international trade has drastically evolved since the 1990s.

Many researchers have tried to explain factors underlying countries' export performance. Paper by Tyszynski (1951) provided a fundamental analytical tool in examining a country's export performance. The analytical tool is then famous as Constant Market Shares (CMS). ${ }^{1}$ He broke down the change in a country's share of exports into two components i.e. the constant share (hypothetical exports) and the competitiveness effect. The more comprehensive and applicable version of the CMS was proposed by Leamer and Stern (1970). They noted that a country's exports might fail to grow rapidly as the world average for three reasons. First,

${ }^{1}$ Since then the CMS has been employed by many authors such as Fleming and Tsiang (1956), Baldwin (1958), Junz and Rhomberg (1965), Leamer and Stern (1970), Richardson (1971a, 1971b), Fagerberg and Sollie (1987) and James and Movshuk (2004), among others. 
exports may be concentrated relatively in commodities for which demand is growing slowly. Second, exports may be going primarily to relatively stagnant regions. Third, the country in question may have been unable or unwilling to compete effectively with other sources of supply.

Although Richardson (1971a, 1971b) asserted some shortcomings of the CMS, those do not reduce the popularity of the CMS. Fagerberg and Sollie (1987) argued that the CMS method could be improved in theoretical consistency and in empirical applicability if initial years' weights (Laspeyres indices) are employed throughout the calculation and the economic interpretation of the residual terms is made explicitly (instead of including them in an arbitrary way in some of other effects). Therefore, they tried to explain factors underlying the changes in a country's shares in world exports. They found that the change in the country's shares in world exports can be broken into five effects i.e. market shares, market distribution, commodity composition, commodity adaptation and market adaptation effects.

The aim of this paper is to develop another version of the CMS method that avoids some problems and weaknesses clearly outlined by Richardson (1971a, 1971b) and Fagerberg and Sollie (1987). And then, it is applied to analyze the export performances of some regions - the European Union (EU), the North American Free Trade Area (NAFTA), the Association of South East Asian Nation (ASEAN) and North East Asia for the period 1980-2005. The rest of this paper is organized as follows. Section II describes the trends in exports of some regions and East Asian countries. Section III exhibits the development of CMS methods. Combining Tyszynski (1951), Richardson (1971a, 1971b) and Fagerberg and Sollie (1987) works, this paper derives another version of the CMS method by Leamer and Stern. Empirical results are discussed in Section IV. Finally, some conclusions are presented in Section V.

\section{Trends in the World Exports}

The East Asian region has increasingly become one of the dominant regions in the world in term of international trade. Figure 1 shows the shares of some regions in the world exports in 1985 and 2006. The East Asia and the EU have taken greater portion of the world exports in 1985 and 2006. The ASEAN covered 4.23 per cent of the world exports in 1985 and it became $6.14 \%$ in 2006. Similarly, the North East Asia had a significant increase in the share, from 16.16\% in 1985 to $18.93 \%$ in 2006 . A tremendous increase in the share was noted by the EU from 
Figure 1. Shares of regions in the world exports
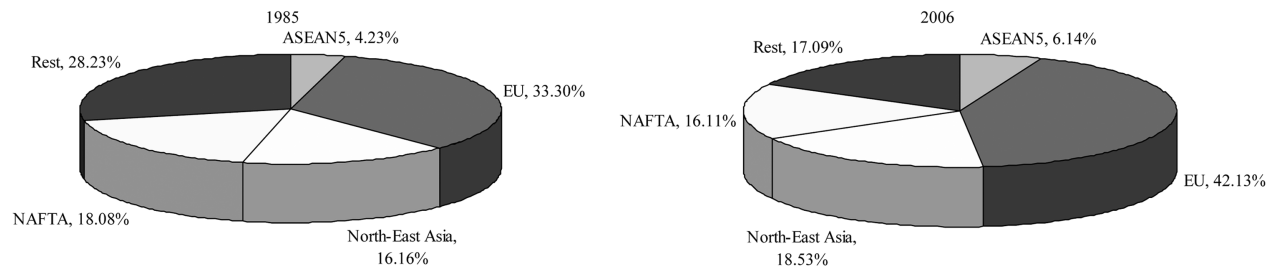

Source: UN-COMTRADE, author's calculation

$33.30 \%$ in 1985 to $42.13 \%$ in 2006 . In contrast, the NAFTA had a decrease in the share from $18.08 \%$ in 1985 to $16.11 \%$ in 2006 .

The world exports have changed drastically parallel with the world trade liberalization. Figure 2 shows trends in the exports value of the world and some regions (the EU, NAFTA, ASEAN and North East Asia). The sharp increases in the world exports during the period 1976-1995 were followed by the steady increases during the period 1995-2001 and then by the sharper increases during the period 2001-2006. All regions' trends in exports relatively had similar pattern to that of the world with different rates of change. During the period 2001-2006, the EU and North East Asia had more drastic increase in their exports than the NAFTA and ASEAN had.

Figure 2. Exports by regions

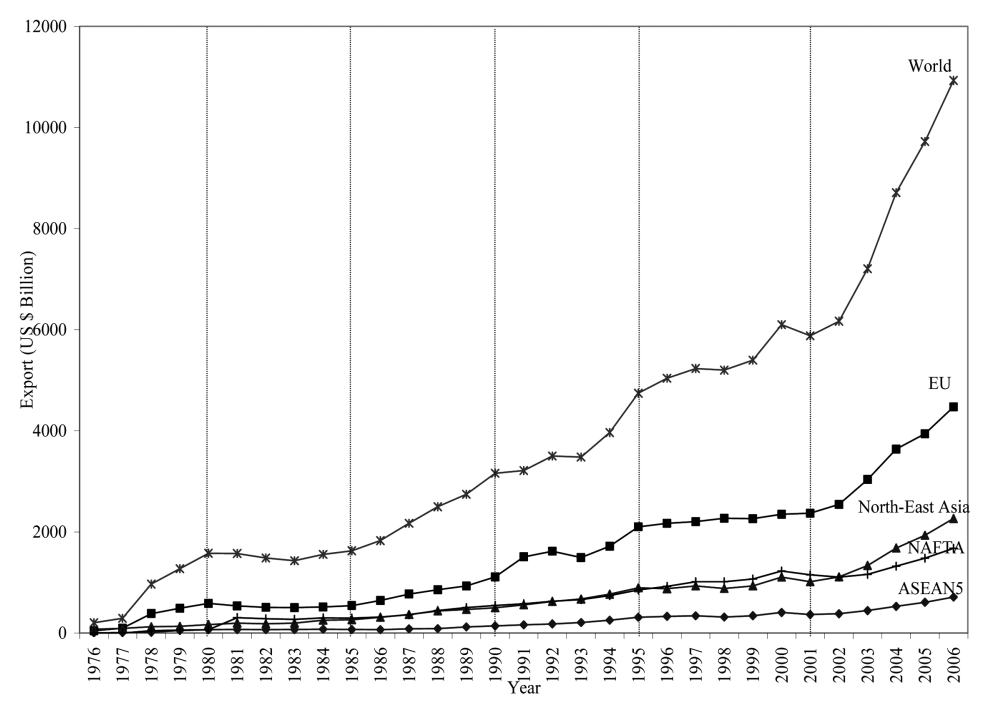

Source: UN-COMTRADE, author's calculation 
Individual countries in the East Asian region also have similar trend in exports to that of the world. Figure 3 shows the trends in exports by individual countries in the East Asian region. It seems that Korea and the ASEAN countries have parallel trends in exports. Japan had a steady positive trend in exports during the period 1976-1995 but it became fluctuated during the period 1995-2001. Japan had a similar trend in exports with that of the EU except during the period 1995-2001. However, since 2001 Japan has had a sharper upward trend in exports and it seems to be in the long run trend. Amazingly, China has made a remarkable upward trend in exports especially since 2001. China's exports have achieved a record i.e. exceeding Japan's exports since 2004. It is interesting to analyze the factors underlying the changes in exports. By using the Constant Market Share analysis, it is possible for us to analyze the factors affecting the changes in exports.

\section{The Constant Market Shares: New Version}

The CMS method is derived from the constant share norm. Tyszynki (1951) calculated the aggregate market share of a country on the world market would have been if its market share in individual commodity groups had remained constant (hypothetical). He referred to the difference between the hypothetical market share and the initial share as the changes in the market share due to structural changes in world trade. The residual -the difference between the final and the hypothetical market share- was referred to as change caused by changes in competitiveness. This method is recognized as "constant market shares (CMS) analysis".

There are two prominent versions of CMS method, i.e. by Leamer and Stern (1970) and Fagerberg and Sollie (1987) (See Appendix A for the detail development and the derivation of the method). This paper would argue that the two versions are incomparable, but complementary. They have different focuses. Stern and Leamer focused on factors underlying the changes in exports $\left(\boldsymbol{V}_{. .}^{4 t}-\boldsymbol{V}_{. .}^{40}\right)$ which also may be represented as the growth of exports, either using Laspeyres index $\left(\frac{\boldsymbol{V}_{*}^{A t}-\boldsymbol{V}_{*}^{A 0}}{\boldsymbol{V}_{.}^{A 0}}\right)$ or Paasche index $\left(\frac{\boldsymbol{V}_{. \cdot}^{A t}-\boldsymbol{V}_{. \bullet}^{A 0}}{\boldsymbol{V}_{.}^{A t}}\right)$. Meanwhile, Fagerberg and Sollie (1987) examined factors underlying the changes in shares of exports $\left(\frac{V_{. .}^{4 t}}{V_{. .}^{W /}}-\frac{V_{. .}^{40}}{V_{. .}^{W V}}\right)$. In other words, since the market share shows the competitiveness this paper argues that Fagerberg and Sollie actually focused on factors underlying the change in country's competitiveness, not the change in exports as described by Leamer and Stern (1970). 
This paper derives another version of the CMS method by Leamer and Stern (1970) based on the change in share of exports by Fagerberg and Sollie (1987). Increasing in the market share implies increasing competitiveness. The share of exports of a given country $\left(S^{A}\right)$ is a function of the country's relative “competitiveness" (Richardson, 1971a):

$$
S^{A} \equiv \frac{V^{A} .}{V^{W} .}=f\left(\frac{c}{C}\right)
$$

where $f^{\prime}()>0, s^{A}$ is the export share of the focus country $A ; \boldsymbol{V}^{A}$. and $\boldsymbol{V}^{W}$. are total exports of the focus country A and the world, respectively; $\mathrm{c}$ and $\mathrm{C}$ are "competitiveness" of the focus country and the world, respectively. Taking derivative with respect to time $(\mathrm{t})$ will result:

$$
\frac{d V^{A} .}{d t}=S^{A} \frac{d V^{W}}{d t}+V^{w} . . \frac{d S^{A}}{d t}=S^{A} \frac{d Q}{d t}+V^{W} . . \frac{d f\left(\frac{c}{C}\right)}{d t}
$$

or

$$
\begin{aligned}
{ }^{\circ} & \stackrel{\circ}{V^{A}}=S^{A} V_{. .}^{W}+V_{. .}^{W} S^{A} \\
& =S^{A} \stackrel{\circ}{V_{. .}^{W}}+V_{. .}^{W} d f^{\prime}\left(\frac{c}{C}\right)
\end{aligned}
$$

A doted $\left({ }^{\circ}\right)$ variable represents that the derivative of the variables with respect to time $(\mathrm{t})$. In this simplest CMS model, a country's total export growth $\left(\stackrel{\circ}{V^{A}}.\right)$ is explained by a world growth effect $\left(S^{A} \stackrel{\circ}{V} V^{W}.\right)$ and a competitive effect $\left(V^{W} \cdot \stackrel{\circ}{S}^{A}\right)$. The former exhibits the country's growth in exports would have been if it had maintained its export share and the later represents any additional export growth due to changes in relative competitiveness. In term of the discrete time, identity (11) can be written as:

$$
\Delta V^{A} . .=S^{A} \Delta V^{W} .+V^{W} . \Delta S^{A}
$$

Substituting $\Delta \mathrm{S}^{\mathrm{A}}$ with equation (A3 in the Appendix A) by Fagerberg and Sollie (1987), new version of the CMS method by Leamer and Stern (1970) is proposed:

$$
\Delta V_{. .}^{A} \equiv S^{A} \Delta V_{. .}^{W}+V_{. .}^{W}\left(\Delta S_{\alpha}^{A}+\Delta S_{\beta}^{A}+\Delta S_{\delta}^{A}+\Delta M_{\alpha \beta}^{A}+\Delta M_{s \delta}^{A}\right)
$$

Where

$\Delta V_{.}^{A}$. = change of country A's exports 
$S^{A} \Delta V_{.}^{W}$. = change in A's exports due to the general rise of world's export

$V^{W} . \Delta S_{\alpha}^{A}=$ the market share effect

$V^{W} . \Delta S_{\beta}^{A}=$ the commodity composition effect

$V^{W} . \Delta S_{\delta}^{A}=$ the market composition effect

$V^{W} . \Delta S_{\alpha \beta}^{A}=$ the commodity adaptation effect

$\mathrm{V}^{\mathrm{W}} . \Delta \mathrm{S}_{\mathrm{s} \delta}^{\mathrm{A}}=$ the market adaptation effect

In the long form²:

$$
\begin{aligned}
\Delta V_{. .}^{A} \equiv & S_{t}^{A} \Delta V_{. .}^{W}+V_{\cdot . \cdot}^{W 0} \sum_{j}\left(\alpha_{t}^{A j}-\alpha_{0}^{A j}\right) \beta_{0}^{W j} \delta_{0}^{W j} \\
& \text { (a) } \\
& +V^{W 0} \cdot . \sum_{j} \alpha_{0}^{A j}\left(\beta_{t}^{W j}-\beta_{0}^{W j}\right) \delta_{0}^{W j}+V^{W 0} \cdot . s_{0}^{A}\left(\delta_{l}-\delta_{0}\right)
\end{aligned}
$$

$$
+\mathrm{V}_{\cdot}^{\mathrm{W} 0} \sum_{\mathrm{j}}\left(\alpha_{\mathrm{t}}^{\mathrm{Wj}}-\alpha_{0}^{\mathrm{Wj}}\right)\left(\beta_{\mathrm{t}}^{\mathrm{Wj}}-\beta_{0}^{\mathrm{Wj}}\right) \delta_{0}^{\mathrm{Wj}}+\mathrm{V}_{\cdot \cdot}^{\mathrm{W} 0}\left(s_{\mathrm{t}}^{\mathrm{A}}-s_{0}^{\mathrm{A}}\right)\left(\delta_{t}^{\mathrm{A}}-\delta_{0}^{\mathrm{A}}\right)
$$

Equation (6) implies that change in country A's exports can be caused by:

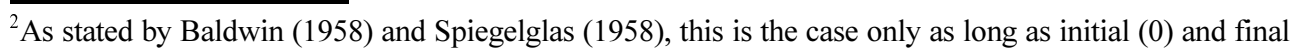
(t) years are used in the calculation. If the first effect is calculated by using initial year $(0)$ then the second effect must necessarily be calculated by using final year $(t)$, vice versa. This implies

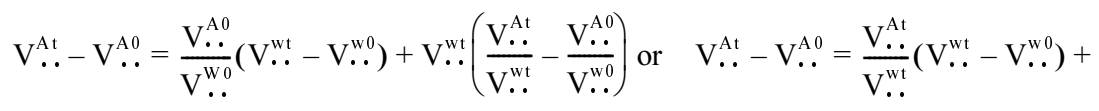

$$
\begin{aligned}
& \mathrm{V}_{\cdot}^{\mathrm{w} 0}\left(\frac{\mathrm{V}_{. \cdot}^{\mathrm{At}}}{\mathrm{V}_{. \cdot}^{\mathrm{wt}}}-\frac{\mathrm{V}_{. \cdot}^{\mathrm{A} 0}}{\mathrm{~V}_{. \cdot}^{\mathrm{w} 0}}\right) .
\end{aligned}
$$

Accordingly, Equation (6) alternatively can be written as:

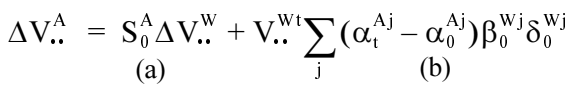

$$
\begin{aligned}
& +\mathrm{V}^{\mathrm{Wt}} \cdot \sum_{\mathrm{j}} \alpha_{0}^{\mathrm{Aj}}\left(\beta_{\mathrm{t}}^{\mathrm{Wj}}-\beta_{0}^{\mathrm{Wj}}\right) \delta_{0}^{\mathrm{Wj}}+\mathrm{V}^{\mathrm{Wt}} \cdot . \mathrm{s}_{0}^{\mathrm{A}}\left(\delta_{1}-\delta_{0}\right) \\
& +\mathrm{V}_{\cdot}^{\mathrm{Wt}} \cdot \sum_{\mathrm{j}}\left(\alpha_{\mathrm{t}}^{\mathrm{Wj}}-\alpha_{0}^{\mathrm{Wj}}\right)\left(\beta_{\mathrm{t}}^{\mathrm{Wj}}-\beta_{0}^{\mathrm{Wj}}\right) \delta_{0}^{\mathrm{Wj}}+\mathrm{V}_{\cdot . \cdot}^{\mathrm{Wt}}\left(\mathrm{s}_{\mathrm{t}}^{\mathrm{A}}-\mathrm{s}_{0}^{\mathrm{A}}\right)\left(\delta_{1}^{\mathrm{A}}-\delta_{0}^{\mathrm{A}}\right)
\end{aligned}
$$


(a) The general changes in the world's export. The country A's exports changes because the world's total exports changes.

(b) The market share effect. It measures the effect of changes in the micro shares of country A in each market weighted by the commodity composition of each market and the country composition of total world exports in the initial year. The country A's exports changes due to the changes in its market share.

(c) The commodity composition effect. It represents that the country A's exports changes due to the changes in commodity compositions of its exports.

(d) The market composition effect. It measures the effect on the market share of a country in the world market of changes in the composition of the market. It shows that the country A's exports changes due to the changes in market composition of its exports.

(e) The commodity adaptation effect. It measures to what degree a country has succeeded in adapting the commodity composition of its exports to the changes in the commodity composition of the market. Fagerberg and Sollie (1987) name it as the 'relative commodity adaptation effect' or just simply 'commodity adaptation effect'. If the commodity adaptation effect equals zero, it does not necessarily means that no adaptation takes place, but that the country adapts its export structure at exactly the same rate as the average of all countries exporting to the market in question.

(f) The market adaptation effect. It can be interpreted as the degree of success of the country in adapting the market composition of its export to the changes in the country composition of world imports.

There are three main differences between the new version (6) and Leamer and Stern's (1970) version. First, the problem of subjectivity in choosing the market distribution effect or the commodity composition effect to be calculated first in the CMS version by Leamer and Stern's (1970) is avoided in this new version. Second, the new version gives six effects instead of Leamer and Stern's (1970) four effects. In the new version the market adaptation and commodity adaptation effects are introduced instead of Leamer and Stern's residual effect. Clear economic interpretation of the two effects is also given. Third, Laspeyres index is employed throughout the calculations. Therefore, lack of comparability due to differences in weighting procedures is avoided (Fagerberg and Sollie, 1987). 


\section{Empirical Results}

To show the empirical relevance of the new version (6), it is applied to scrutinize the export performance of some regions (the EU, NAFTA, ASEAN and North East Asia) for the periods 1980-1985, 1985-1990, 1990-1995, 1995-2001, and 20012006. These periods are chosen by considering the fact that the steady increase in the world exports during the period 1976-1995 was followed by the slower increase during the period 1995-2001 and by the sharper increase during the period 2001-2006 as described in the section II.

For each region and each country, the change in exports is decomposed into the six effects discussed in the previous section. This paper uses data on exports 3-digit SITC Revision 2 by products and destinations published by the United Nations (UN) namely United Nations Commodity Trade Statistics Database (UNCOMTRADE). It applies the definitions of products by the Empirical Trade Analysis (ETA). On the basis of the United Nations Conference on Trade and Development (UNCTAD) / World Trade Organization (WTO) classification using the SITC Rev. 3, the ETA distinguished the following products: (a) Primary products (83 SITC), (b) Natural resource-intensive products (21 SITC), (c) Unskilled labor-intensive products (26 SITC), (d) Technology-intensive products (62 SITC), (e) Human-capital intensive products (43 SITC), (f) Others (5 SITC) (See Appendix B for he detailed classification). This paper defines the export destinations consisting of the ASEAN, the North East Asia, the EU and the NAFTA and the rest of the world (Rest).

Table 1 and Figure 3 show the CMS analysis for the regions. The change in total exports and the shares of each effect (in \%) in the periods under consideration are presented in the columns. It is clearly shown that during the period 1980-1995, the exports of all regions were not caused by the general rise in world exports. The increases of exports were caused by other factors than the general rise in world exports. In the case of the EU, the increase in her exports was mainly caused by the market composition effect. Meanwhile, the NAFTA's increasing exports were mainly due to the market share and market adaptation effects. The increase in exports of the North East Asian region was largely caused by the market adaptation effect.

In the case of the ASEAN5, all the effects were very high but they are in the opposite direction. It implies that during the period 1980-1985, the export performance of the ASEAN5 was so dynamic. This is supported by the fact that 
Figure 3. The CMS Analysis: EU, NAFTA, North East Asia, ASEAN and RoW

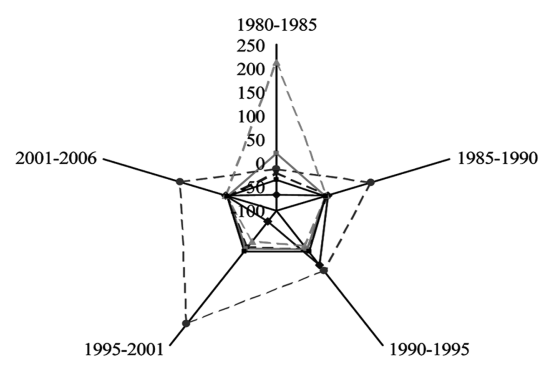

(a) EU

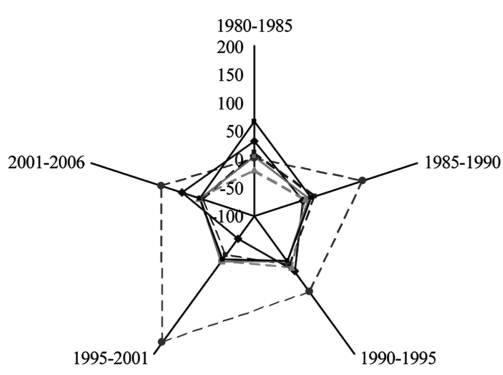

(c) North East Asia

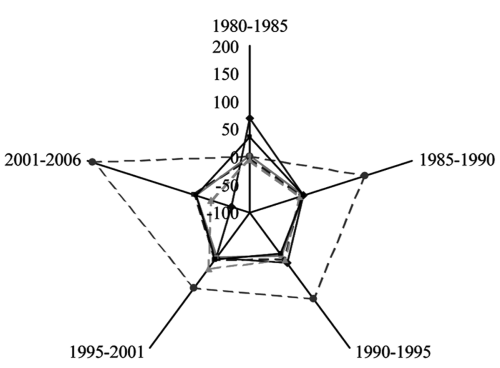

(b) NAFTA

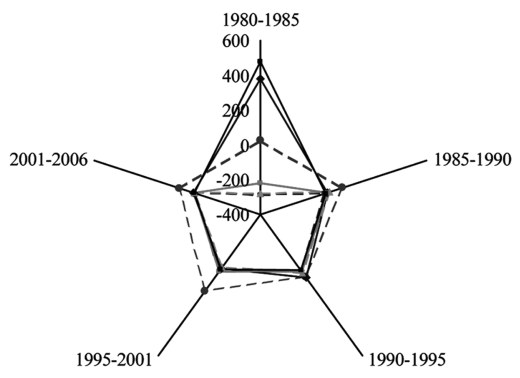

(d) ASEAN5

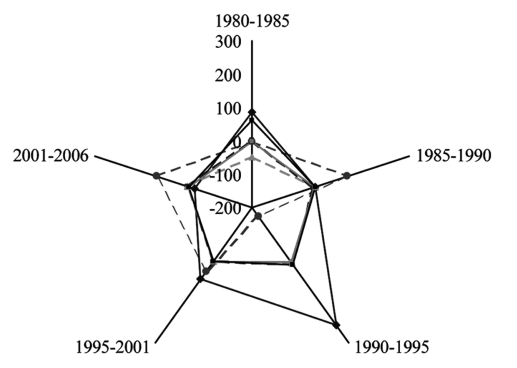

- - General rise in world exports
$\rightarrow-$ Market share
-- Commodity composition
$-\longleftarrow$ Market composition
$\rightarrow-$ Commodity adaptation
$\rightarrow-$ Market adaptation

(e) Rest of the World

Source: UN-COMTRADE, author's calculation

the foreign direct investments (FDI), especially from Japan, have influenced the ASEAN5 countries comparative advantage. FDI is affected by location, transaction cost and internalization advantages. Location advantages are determined by domestic market, the availability of suppliers and human resources, factors endowment, transportation cost (infrastructures), and the investment facilities measures (including tax incentive, subsidy, etc) provided by the governments. Transaction cost relates with contracts, which cover identification (i.e. concerning reward and punishment, dispute, etc), implementation and monitoring. Advantages of doing international business activities are related with the ownership of firms. 
Table 1. The CMS Analysis: Some Regions

\begin{tabular}{|c|c|c|c|c|c|c|c|}
\hline \multirow[b]{2}{*}{ Regions } & \multirow[b]{2}{*}{$\begin{array}{c}\text { Change in } \\
\text { Export (\$ US) }\end{array}$} & \multicolumn{6}{|c|}{ Due to $(\%)$} \\
\hline & & $\begin{array}{l}\text { General } \\
\text { rise } \\
\text { in world } \\
\text { exports }\end{array}$ & $\begin{array}{c}\text { Market } \\
\text { share }\end{array}$ & $\begin{array}{l}\text { Commod- } \\
\text { ity } \\
\text { composi- } \\
\text { tion }\end{array}$ & $\begin{array}{c}\text { Market } \\
\text { compo- } \\
\text { sition }\end{array}$ & $\begin{array}{l}\text { Commod- } \\
\text { ity adap- } \\
\text { tation }\end{array}$ & $\begin{array}{c}\text { Market } \\
\text { adaptation }\end{array}$ \\
\hline \multicolumn{8}{|l|}{$\overline{\mathrm{EU}}$} \\
\hline 1980-1985 & $-42,312,516,458$ & -12.5 & -66.5 & -20.4 & 213.0 & 21.0 & -34.5 \\
\hline $1985-1990$ & $565,284,106,231$ & 92.1 & 4.1 & 3.1 & 1.3 & -0.3 & -0.3 \\
\hline 1990-1995 & $985,560,243,598$ & 57.2 & 41.4 & 0.7 & -7.5 & 1.5 & 6.7 \\
\hline $1995-2001$ & $255,376,839,742$ & 193.9 & -73.6 & -5.0 & -19.8 & -0.5 & 4.9 \\
\hline $2001-2006$ & $2,132,901,664,724$ & 95.4 & 2.3 & -0.5 & 3.0 & 0.0 & -0.2 \\
\hline \multicolumn{8}{|l|}{ NAFTA } \\
\hline $1980-1985$ & $229,064,546,136$ & 0.3 & 69.6 & -1.5 & -6.0 & 2.4 & 35.3 \\
\hline $1985-1990$ & $252,110,703,572$ & 113.8 & -0.5 & -3.9 & -7.7 & -0.8 & -1.0 \\
\hline 1990-1995 & $307,513,205,593$ & 91.0 & 12.8 & 3.0 & 5.7 & -4.6 & -8.0 \\
\hline $1995-2001$ & $296,865,124,180$ & 68.3 & 0.9 & 4.6 & 24.3 & -0.9 & 2.8 \\
\hline $2001-2006$ & $524,521,576,640$ & 190.7 & -66.2 & 3.7 & -28.2 & -0.1 & 0.1 \\
\hline \multicolumn{8}{|c|}{ North East Asia } \\
\hline $1980-1985$ & $83,950,312,412$ & 1.8 & 31.8 & 12.7 & -18.0 & 4.3 & 67.4 \\
\hline 1985-1990 & $245,965,384,960$ & 100.0 & -11.2 & 10.8 & -5.0 & 0.8 & 4.6 \\
\hline 1990-1995 & $394,419,248,361$ & 64.7 & 20.5 & 5.2 & 11.0 & -0.1 & -1.3 \\
\hline $1995-2001$ & $120,698,001,433$ & 175.7 & -51.0 & -15.0 & -2.7 & -1.0 & -5.9 \\
\hline 2001-2006 & $1,250,523,763,181$ & 70.4 & 32.9 & -4.4 & 1.6 & -0.9 & 0.3 \\
\hline \multicolumn{8}{|l|}{ ASEAN } \\
\hline 1980-1985 & $2,298,828,307$ & 26.6 & 381.0 & -289.9 & -281.0 & -217.7 & 480.9 \\
\hline 1985-1990 & $70,278,175,887$ & 95.5 & 4.7 & -16.5 & 16.7 & 7.1 & -7.5 \\
\hline 1990-1995 & $172,246,567,596$ & 41.4 & 46.6 & -4.1 & 15.1 & 3.4 & -2.4 \\
\hline $1995-2001$ & $51,798,578,630$ & 142.8 & -14.8 & 7.0 & -25.8 & 4.4 & -13.7 \\
\hline 2001-2006 & $348,114,593,172$ & 90.7 & 7.0 & -0.9 & 2.6 & 0.4 & 0.1 \\
\hline \multicolumn{8}{|c|}{ Rest of the World } \\
\hline 1980-1985 & $-69,534,603,370$ & -17.9 & -165.5 & 97.5 & 317.8 & 2.1 & -134.0 \\
\hline 1985-1990 & $1,296,565,534,480$ & 96.3 & 8.4 & -1.7 & -6.1 & 0.0 & 3.0 \\
\hline 1990-1995 & $1,206,765,438,781$ & 109.4 & 3.2 & 0.1 & -15.4 & -0.8 & 3.5 \\
\hline $1995-2001$ & $1,001,811,398,856$ & 89.7 & 5.5 & 2.9 & 0.3 & 0.4 & 1.3 \\
\hline $2001-2006$ & $3,832,094,025,864$ & 108.5 & -10.1 & 1.0 & 0.5 & 0.6 & -0.5 \\
\hline
\end{tabular}

Source: UN-COMTRADE, author's calculation 
For instance, Thailand allowed foreign capital participation for exports in 1983, Malaysia and Indonesia followed to relax foreign capital participation in 1986, and the Philippines followed suit in 1991 (Hiratsuka, 2006). The flying geese pattern has been observed in the shifts of comparative advantages in East Asia through FDI. Japanese FDI, which goes to East Asian countries, is more 'pro-trade' type of FDI (Kojima, 1995).

Since 1985 the general rise in world exports has dominated all regions' exports performance. This fact has supported the constant share norm. All regions have relied on the general rise in world exports. However, massive proliferation of regionalization and economic integration in the early 1990s caused the increases in intra-regional trade. The EU was established in 1993 under the Maastricht Treaty, the NAFTA came into effect in 1994. The ASEAN Free Trade Area (AFTA) was started in 1992 through the Common Effective Preferential Tariff (CEPT). Through trade creation and trade diversion, the establishments of economic integration have changed exports destinations which intra-regional trade may take place in the larger portion. As results during the period 1990-1995, the general rise in world exports had smaller portions in affecting regions' export performance i.e. $57.2 \%$ in the EU, $64.7 \%$ in the North East Asian region, and $41.4 \%$ in the ASEAN. The decrease was followed by the increase in the market share effect i.e. $41.4 \%$ in the EU, 20.5\% in the North East Asian region, $46.6 \%$ in the ASEAN. The NAFTA has smaller effect from the general rise in world exports i.e. $68.3 \%$ during the period 1995-2001 just after the establishment. In addition, the decrease was followed by the increase in the market composition effect.

The general rise in world exports has dominated the regions' exports performance since 2001. Again, the constant share norm works. From these figures, it might be firmly asserted that the establishments of economic integration affect the exports performance in short terms. The increasing intra-regional trade (trade creation and trade diversion) gives impacts on regions' trade performance right after the establishment of economic integration. The constant share norm will work again afterward. The EU, North East Asia and ASEAN had decreases in the market share effect and increases in the general rise of world exports for the period 1995-2005.

\section{Conclusions}

The world exports have increased drastically since the world liberalization has 
taken place. This paper analyzes the factors underlying regions' and countries' changes in exports using the Constant Market Share (CMS) method. Firstly, the CMS concepts are comprehensively described, especially works by Leamer and Stern (1970), Richardson (1971a, 1971b) and Fagerberg and Sollie (1987). This paper argues that the two versions by Leamer and Stern (1970) and Fagerberg and Sollie (1987) are incomparable but complementary. There are different points of view between them. Leamer and Stern' version focuses their analysis on factors underlying a country's changes in exports. Meanwhile, Fagerberg and Sollie's version explain factors underlying country's changes in shares in the world export.

Secondly, combining the two versions this paper comes out with another version of the CMS which decomposes the change in a country's export into six effect instead of two effects (by Tyszynki) or four effects (by Leamer and Stern. The six effects are (a) general changes in world exports, (b) market share effects, (c) commodity composition effect, (d) market composition effect, (e) commodity adaptation effect, (f) market adaptation effect. This new version has some advantages. First, the problem of subjectivity in the choice of which effects- i.e. the market distribution effect or the commodity composition effect- coming first is avoided. Second, the market adaptation and commodity adaptation effects are introduced instead of Leamer and Stern's residual effect and clear economic interpretation of the two effects is also given. Third, lack of comparability due to differences in weighting procedures is avoided. However, the use of the initial and final years as still problematic since two possible formulas can come out (Baldwin; 1958; Spiegelglas, 1958). Since the change in exports is the focus of the CMS method, this problem is unavoidable unlike the Fagerberg and Sollie's version which focus on the change in share of exports.

When applied to some regions (EU, NAFTA, ASEAN and North East Asia), some interesting empirical results are found. First, the constant share norm seems powerful in explaining exports performance the regions and countries since the mid 1980s. The general rise in world's exports is the main source of the increase of exports. Before the mid 1980s, the pattern of exports was unpredictable. During the period 1980-1985 the decrease of EU exports was mainly caused by the market share and market adaptation effects. The increases of exports of NAFTA, North East Asian region and ASEAN were mainly affected by the market share and market adaptation effect. Second, the proliferation of regionalism and economic integrations in the beginning 1990s caused the change in trade pattern. Intraregional trade has increased significantly. Trade creation and trade diversion 
occurs. As a result, the power of the constant share norm in explaining a country's exports performance decreased during 1990-1995. As far as intra-regional trade increases, the market share and market composition effect become dominant factors underlying country's exports. However, the change in trade pattern only happened in short term (in the beginning of economic integration) i.e. 1990-1995 in the case of the EU, the North East Asia and the ASEAN and 1995-2001 in the case of the NAFTA.

Received 30 January 2010, Revised 20 July 2010, Accepted 27 July 2010

\section{References}

Aiginger, K. (1999), "Do Industrial Structures Convergence? A Survey of the Empirical Literature on Specialization and Concentration of Industries", Austrian Institute of Economic Research (WIFO) - Working Paper, Vol. 116, Vienna.

Ashby, L.D. (1964), "The Geographical Redistribution of Employment: an Examination of the Element Change", Survey of Current Business, Vol. 44, pp.13-20.

Baldwin, R.E. (1958), "The Commodity Composition of World Trade: Selected Industrial Countries 1990-1954”, Review of Economics and Statistics, Vol. 40, pp. 50-71.

Fagerberg, J. and Sollie, G., (1987), "The Method of Constant Market Shares Analysis Reconsidered", Applied Economics, Vol. 19, pp. 1571-1583.

Fleming, J.M. and Tsiang, S.C. (1958), "Changes in Competitive Strength and Export Shares of Major Industrial Countries", International Monetary Fund - Staff Papers, V (August), pp. 218-248.

Houston, D.B. (1967), "The Shift and Share Analysis of Regional Growth: a Critique", Southern Economic Journal, Vol. 33, pp. 577-581.

Hiratsuka, D., (2006), "Vertical Intra-regional Production Networks in East Asia: a Case Study of the Hard Disc Drive industry", In D. Hiratsuka, ed. 2006. East Asia's De Facto Economic Integration. New York: Palgrave Macmillan, pp. 181-99.

James, W.E. and Movshuk, O. (2004), "Shifting International Competitiveness: an Analysis of Market Share in Manufacturing Industries in Japan, Korea", Taiwan and the USA. Asian Economic Journal, Vol. 18 (21), pp. 121-148.

Kojima, K., (1995), "Dynamics of Japanese Direct Investment in East Asia”, Hitotsubashi Journal of Economics, Vol. 36, pp. 93-124.

Junz, H.B. and Rhomberg, R.R. (1965), "Prices and Export Performance of Industrial Countries", 1953-63. International Monetary Fund - Staff Papers, XII (July), pp. 224-269.

Krugman, P.R. (1995), “Growing World Trade: Causes and Consequences,” Brooking Papers on Economic Activity, $25^{\text {th }}$ Anniversary Issue, pp. 327-77.

Leamer, E.E. and Stern, R.M. (1970), "Quantitative International Economics”, Aldine 
Publishing Co. Chicago.

Richardson, J.D., (1971a), "Constant Market Share of Export Growth", Journal of International Economics Vol. 1, pp. 227-239.

Richardson, J.D., (1971b), Some Sensitivity Tests for a "Constant-Market-Share" Analysis of Export. The Review of Economics and Statistics, LIII (4), pp. 300-304. Spiegelglas, S., (1959), "World Exports of Manufactures", 1956 vs. 1937. The Manchester School, Vol. 27, pp. 111-39.

The United Nations (2007), United Nation Commodity Trade Statistics Database (UNCOMTRADE. [Online; cited on December 4, 2007]. Available from URL:http:// comtrade.un.org/db/default.aspx.

Trung, N.K. and Hashimoto, Y. (2005), "Economic Analysis of ASEAN Free Trade Area; by Country Panel Data", Discussion Papers in Economic and Business No 05-12, Graduate School of Economics and Osaka School of International Public Policy (OSIPP), Japan.

Tyszynski, H., (1951), "World Trade in Manufactured Commodities", 1899-1950. The Manchester School, vol. 19, pp. 111-139.

Wörz, J. (2005), "Dynamic of Trade Specialization in Developed and Less Developed countries", Emerging Markets Finance and Trade, Vol. 41(3), pp. 92-111.

\section{Appendix}

\section{A. Constant Market Shares (CMS) Method}

The appendix A discusses two influential versions of the CMS method i.e. the changes in exports (Leamer and Stern, 1970) and the changes in shares of exports (Fagerberg and Solie, 1987).

\section{A.1. The Change in Exports}

Suppose there are number of exporter countries $(z)$ in the world and number of importer countries $(\mathrm{k})$. Exporter country A is a country in question. Some definitions are firstly determined:

$V_{i}^{W 0}$. $=$ value of the world's exports of commodity $i$ in period 0

$V_{i}^{W t}$. $=$ value of the world's exports of commodity $i$ in period $\mathrm{t}$

$V_{._{j}}^{W 0}=$ value of the world's exports to country $j$ in period 0

$V_{._{j}}^{W t}=$ value of the world's exports to country $j$ in period $\mathrm{t}$

$V_{i j}^{W 0}=$ value of the world's exports of commodity $i$ to country $j$ in period 0

$V_{i j}^{W t}=$ value of the world's exports of commodity $i$ to country $j$ in period $t$

$V_{. .}^{W 0}=$ value of the world's exports in period 0

$V_{. .}^{W t}=$ value of the world's exports in period $t$ 
$V_{i}^{A 0}=$ value of country A's exports of commodity $i$ in period 0

$V_{i}^{4 t}=$ value of country A's exports of commodity $i$ in period $t$

$V_{\cdot j}^{40}=$ value of country A's exports to country $j$ in period 0

$V_{{ }^{\prime} j}^{A t}=$ value of country A's exports to country $j$ in period $t$

$V_{i j}^{40}=$ value of country A's exports of commodity $i$ to country $j$ in period 0

$V_{i j}^{t t}=$ value of country A's exports of commodity $i$ to country $j$ in period $t$

$r=$ percentage increase in total world exports;

$$
r=\frac{V_{. \cdot}^{W t}-V_{. \cdot}^{W 0}}{V_{\cdot .}^{W 0}}
$$

$r_{i}=$ percentage increase in world exports of commodity i;

$$
r_{i}=\frac{V_{i \bullet}^{W t}-V_{i \bullet}^{W 0}}{V_{i \bullet}^{W 0}}
$$

$r_{i j}=$ percentage increase in world exports of commodity $\mathrm{i}$ to country $\mathrm{j}$;

$$
r_{i j}=\frac{V_{i j}^{W t}-V_{i j}^{W 0}}{V_{i j}^{W 0}}
$$

Leamer and Stern (1970) formulated the CMS as follows:

$$
\begin{aligned}
V_{. .}^{A t}-V_{.}^{A 0} & \equiv \sum_{i} \sum_{j} r_{i j} V_{i j}^{A 0}+\sum_{i} \sum_{j}\left(V_{i j}^{A t}-V_{i j}^{A 0}-r_{i j} V_{i j}^{A 0}\right) \\
& \equiv r V_{.}^{A 0}+\sum_{i}\left(r_{i}-r\right) V_{i \cdot}^{A 0}+\sum_{i} \sum_{j}\left(r_{i j}-r_{i}\right) V_{i j}^{A 0}+\sum_{i} \sum_{j}\left(V_{i j}^{A t}-V_{i j}^{A 0}-r_{i j} V_{i j}^{A 0}\right)
\end{aligned}
$$

(a)

(b)

(c)

(d)

or

$$
V_{. .}^{A t}-V_{. .}^{A 0} \equiv r V_{. .}^{A 0}+\sum_{j}\left(r_{j}-r\right) V_{\cdot j}^{A 0}+\sum_{i} \sum_{j}\left(r_{i j}-r_{j}\right) V_{i j}^{A 0}+\sum_{i} \sum_{j}\left(V_{i j}^{A t}-V_{i j}^{A 0}-r_{i j} j_{i j}^{A 0}\right)
$$

(a) (d)

Expression (A.1) shows that the increase of country A's exports $\left(V_{. .}^{A t}-V_{. .}^{40}\right)$ can be divided into four components associated with: (a) the general rise in world exports, $\left(r V^{40}\right)$; (b) the commodity composition of country A's exports, $\left(\sum_{i}\left(r_{i}-r\right) V_{i}^{A 0}\right) ;(\mathrm{c})$ the market distribution of country A's exports, $\left(\sum_{i} \sum_{j}\left(r_{i j}-r_{i}\right) V_{i j}^{A 0}\right)$ 
; and (d) an unexplained residual (the competitive effect) $\left(\sum_{i} \sum_{j}\left(V_{i j}^{A t}-V_{i j}^{A 0}-r_{i j} V_{i j}^{A 0}\right)\right)$. The commodity composition effect would be positive if A has concentrated on the export of commodities whose markets were growing relatively fast and would be negative if A has concentrated in slowly growing commodity markets. The market distribution effect will be positive if country A has concentrated its exports in markets with relatively rapid growth.

\section{A.2. The Shortcomings of the Leamer and Stern's Version}

Richardson (1971b) noted some shortcomings of application of the CMS method by Leamer and Stern. First, the various components in the basic identity (1) will vary with the level of commodity aggregate i.e. the composition of class $i$. Therefore, commodity classification (i) should be as homogeneous as possible. Second, the CMS effects will vary with the degree of market consolidation, i.e. the identity of each market (j). Third, which identities either (A.1) or (A.2) applied is somewhat arbitrary. It depends on the researcher's subjectivity. In (A.1), the commodity effect $\left(\sum_{i}\left(r_{i}-r\right) V_{i}^{A 0}\right)$ is calculated "before" the market effect $\left(\sum_{i} \sum_{j}\left(r_{i j}-r_{i}\right) V_{i j}^{A 0}\right)$. In contrast, in (A.2) the market effect $\left(\sum_{j}\left(r_{j}-r\right) V_{\cdot j}^{A 0}\right)$ is calcu lated "before" the commodity effect $\left(\sum_{i} \sum_{j}\left(r_{i j}-r_{j}\right) V_{i j}^{40}\right)$. Even if the sum of the two effects would be the same, this change in the sequence of calculation would change the values of the individual commodity and market effects.

Fourth, alternative choice of the world or standard area will cause CMS to vary. In principle, the appropriate "world" (i.e. the area to which the denominator of an export shares refers) should include only true competitor. Fifth, the ability to make more than one choices of calculation basis represents the index number problem, for example Laspeyres Index and Paasche Index.

\section{A.3. The Change in Share of Exports}

The interpretation of competitiveness effect (d) in the expression (A.1) or (A.2) is not as straight forward as the other ones. There are many other things beside the relative prices affecting a country's competitiveness such as (a) the differential rates of export price inflation, (b) differential rates of quality improvement and the development of new products, (c) differential rates of improvement in the efficiency of marketing or in the terms of financing the sale of export goods, (d) differential changes in the ability for prompts fulfillment of export orders. More recently, Fagerberg and Sollie (1987) developed another version of the CMS 
method by Tyszynski (1951) which gave much more explanation on the competitiveness effect. The following symbols and definitions are used: ${ }^{3}$

$V=$ value of exports;

$i=$ commodities

$j=$ exports (destinations) markets

$n$ = number of commodities;

$k=$ number of countries ( $\mathrm{K}$ is the last exports market)

$0, t=$ subscripts which refer to the initial year and to the final year of the comparison, respectively;

$A=$ country in question

$W=$ world

$V=$ value of exports

$S^{A}=$ market shares of country A in world exports (the ratio of A's total exports and the world total exports;

$$
S^{4}=S^{41}+S^{42}+\ldots+S^{A K}=\frac{\sum_{i} \sum_{j} V_{i j}^{A}}{\sum_{i} \sum_{j} V_{i j}^{W}}
$$

$S^{A}=$ macro share of country A in world exports (the ratio of A's total export and world total export in each market); row vector of dimension $\mathrm{K}$ :

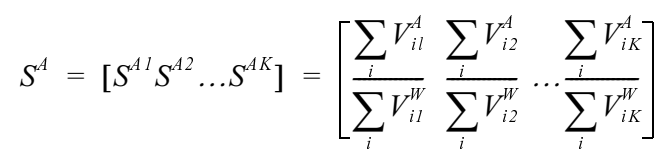

$\alpha^{4 j}=$ market shares, by commodity, of country A (micro share of country A) in the world exports to market $j$ (the ratio of country A's and the world's exports of commodity i to country K); matrix of dimension Kxn:

\footnotetext{
${ }^{3}$ This paper applies variable (data) on exports only, which is slightly different with that of Fagerberg and Sollie (1987). They used term exports of specific country. However, for market destination they employed "total import" of a country instead of "world exports" to the country. Theoretically, the two terms must be the same i.e. the "total imports" value of a country is the same with the "world exports" to the country. In practice, since imports are calculated based on cost-insurance-freight (CIF) meanwhile exports are calculated base on free-on-board (FOB), the use of only exports therefore avoids misleading.
} 


$$
\alpha^{\mathrm{Aj}}=\left[\begin{array}{cccc}
\alpha_{1}^{\mathrm{A} 1} & \alpha_{2}^{\mathrm{A} 1} & \ldots & \alpha_{\mathrm{n}}^{\mathrm{A}} \\
\alpha_{1}^{\mathrm{A} 2} & \alpha_{2}^{\mathrm{A} 2} & \ldots & \alpha_{\mathrm{n}}^{\mathrm{A} 2} \\
\vdots & & \\
\alpha_{1}^{\mathrm{AK}} & \alpha_{2}^{\mathrm{AK}} & \cdots & \alpha_{\mathrm{n}}^{\mathrm{AK}}
\end{array}\right]=\left[\begin{array}{cccc}
\frac{V_{11}^{A}}{V_{11}^{W}} & \frac{V_{21}^{A}}{V_{21}^{W}} & \ldots \frac{V_{n 1}^{A}}{V_{n 1}^{W}} \\
\frac{V_{22}^{A}}{V_{12}^{W}} & \frac{V_{22}^{A}}{V_{22}^{W}} & \ldots \frac{V_{n 2}^{A}}{V_{n 2}^{W}} \\
\vdots & \\
\frac{V_{1 K}^{A}}{V_{1 K}^{W}} & \frac{V_{2 K}^{A}}{V_{2 K}^{W}} & \ldots \frac{V_{n K}^{A}}{V_{n K}^{W}}
\end{array}\right]
$$

$\beta^{W j}=$ commodity shares of the world exports to country $\mathrm{j}$ to the world total exports (the ratio of world's specific commodity exports and total world's exports to country $\mathrm{K}$ ); matrix of dimension $\mathrm{nxK}$ :

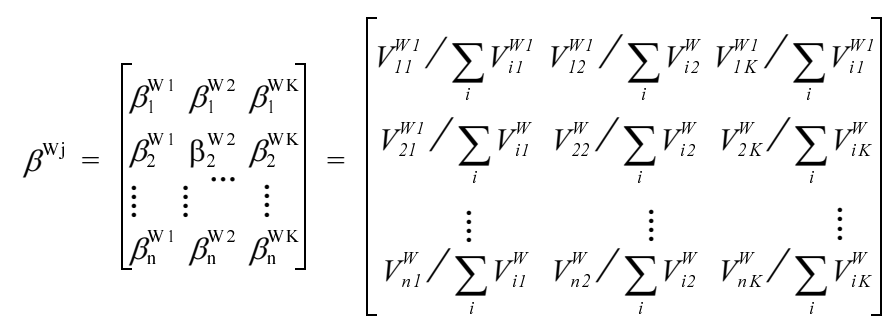

$\delta^{\mathrm{Wj}}=$ country shares of the world exports (the ratio of the world exports to country $\mathrm{j}$ and the world total exports); column vector of dimension $\mathrm{K}$ :

$$
\delta^{W j}=\left[\begin{array}{c}
\delta^{W 1} \\
\delta^{W 2} \\
\vdots \\
\delta^{W K}
\end{array}\right]=\left[\begin{array}{c}
\sum_{i} V_{i l}^{W} \sum_{i} \sum_{j} V_{i j}^{W} \\
\sum_{i} V_{i 2}^{W} \sum_{i} \sum_{j} V_{i j}^{W} \\
\sum_{i} V_{i K}^{W} / \sum_{i} \sum_{j} V_{i j}^{W}
\end{array}\right]
$$

Fagerberg and Sollie (1987) formulated the change in share of exports of country $\left(\Delta S^{A}\right)$ as follows:

$$
\Delta S^{A} \equiv \Delta S_{\alpha}^{A}+\Delta S_{\beta}^{A}+\Delta S_{\delta}^{A}+\Delta S_{\alpha \beta}^{A}+\Delta S_{s \delta}^{A}
$$

Expression (A.3) implies that changes in country A's share in the world exports 
$\Delta \mathrm{S}^{\mathrm{A}}$ can be broken down into five effects i.e. the market share effect, $\Delta S_{\alpha}^{A} ;$ the commodity composition effect, $\Delta S_{\beta}^{A}$; the market composition effect, $\Delta S_{\delta}^{A}$; the commodity adaptation effect, $\Delta S_{\alpha \beta}^{A}$; and the market adaptation effect ${ }^{4}, \Delta S_{s \delta}^{A}$. Further, each effect is formulated as follows:

$$
\begin{aligned}
& \Delta S_{\alpha}^{A}=\sum_{\mathrm{j}}\left(\alpha_{\mathrm{t}}^{\mathrm{Aj}}-\alpha_{0}^{\mathrm{Aj}}\right) \beta_{0}^{\mathrm{Wj}} \delta_{0}^{\mathrm{Wj}} \\
& \Delta S_{\beta}^{A}=\sum_{\mathrm{j}} \alpha_{0}^{\mathrm{Aj}}\left(\beta_{\mathrm{t}}^{\mathrm{Wj}}-\beta_{0}^{\mathrm{Wj}}\right) \delta_{0}^{\mathrm{Wj}} \\
& \Delta \mathrm{S}_{\delta}^{\mathrm{A}}=\mathrm{s}_{0}^{\mathrm{A}}\left(\delta_{\mathrm{t}}^{\mathrm{W}_{\mathrm{j}}}-\delta_{0}^{\mathrm{Wj}_{\mathrm{j}}}\right)
\end{aligned}
$$

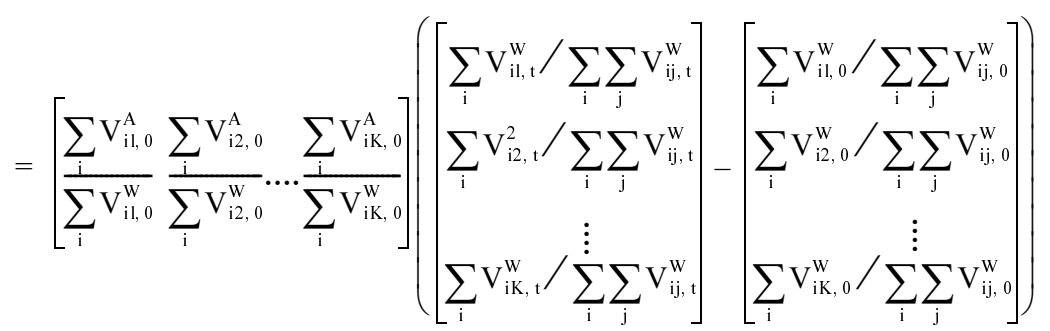

$$
\begin{aligned}
& \Delta \mathrm{S}_{\alpha \beta}^{\mathrm{A}}=\sum_{\mathrm{j}}\left(\alpha_{\mathrm{t}}^{\mathrm{Wj}}-\alpha_{0}^{\mathrm{Wj}}\right)\left(\beta_{\mathrm{t}}^{\mathrm{Wj}}-\beta_{0}^{\mathrm{Wj}}\right) \delta_{0}^{\mathrm{Wj}} \\
& \Delta \mathrm{S}_{\mathrm{s} \delta}^{\mathrm{A}}=\left(\mathrm{s}_{\mathrm{t}}^{\mathrm{A}}-\mathrm{s}_{0}^{\mathrm{A}}\right)\left(\delta_{\mathrm{t}}^{\mathrm{Wj}}-\delta_{0}^{\mathrm{Wj}}\right)
\end{aligned}
$$

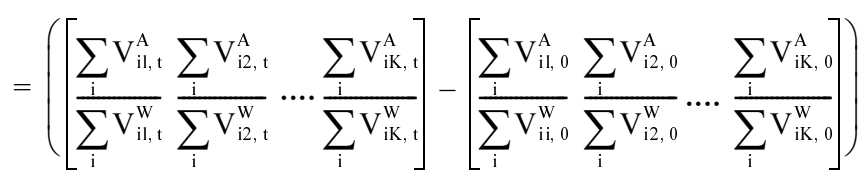

\footnotetext{
${ }^{4}$ Fagerberg and Sollie (1987) explained that the commodity adaptation effect indicates to what extent a country has been successful in adapting the commodity composition of its exports to the changes in the commodity composition of the market. Meanwhile, the market adaptation effect reflects the degree of success of the country in adapting the market composition of its exports to the changes in the country composition of world exports.
} 


$$
\left(\left[\begin{array}{c}
\sum_{\mathrm{i}} V_{i i, t}^{W} / \sum_{\mathrm{i}} \sum_{\mathrm{j}} V_{i j, t}^{W} \\
\sum_{i} V_{i 2, t}^{W} / \sum_{\mathrm{i}} \sum_{\mathrm{j}} V_{i j, t}^{W} \\
\vdots \\
\sum_{\mathrm{i}} V_{i K, t}^{W} / \sum_{\mathrm{i}} \sum_{\mathrm{j}} V_{i j, t}^{W}
\end{array}\right]-\left[\begin{array}{c}
\sum_{\mathrm{i}} \mathrm{V}_{\mathrm{i} 1,0}^{\mathrm{w}} / \sum_{\mathrm{i}} \sum_{\mathrm{j}} V_{i j, 0}^{W} \\
\sum_{\mathrm{i}} \mathrm{V}_{\mathrm{i} 2,0}^{\mathrm{w}} / \sum_{\mathrm{i}} \sum_{\mathrm{j}} V_{i j, 0}^{W} \\
\vdots \\
\sum_{\mathrm{i}} \mathrm{V}_{\mathrm{iK}, 0}^{\mathrm{w}} / \sum_{\mathrm{i}} \sum_{\mathrm{j}} V_{i j, 0}^{W}
\end{array}\right]\right)
$$

\section{B. Product Classification}

Products Classification 3-digit SITC Rev. 2

001, 011, 012, 014, 022, 023, 024, 025, 034, 035, 036, 037, 041, 042, 043, 044, 045, 046, 047, 048, 054, 056, 057, 058, 061, 062, 071, 072,

1. Primary Products 073, 074, 075, 081, 091, 098, 111, 112, 121, 122, 211, 212, 222, 223, $232,233,244,245,246,247,248,251,261,263,264,265,266,267$, $268,269,271,273,274,277,278,281,282,286,287,288,289,291$, $292,322,323,333,334,335,341,351,411,423,424,431,941$

2. Natural-resource $524,611,612,613,633,634,635,661,662,663,667,671,681,682$, Intensive Products $683,684,685,686,687,688,689$

3. Unskilled-labor Inten- 651, 652, 653, 654, 655, 656, 657, 658, 659, 664, 665, 666, 793, 812 , sive Products $821,831,842,843,844,845,846,847,848,851,894,895$ $511,512,513,514,515,516,522,523,541,562,572,582,583,584$,

4. Technology Intensive $585,591,592,598,711,712,713,714,716,718,721,722,723,724$, Products $725,726,727,728,736,737,741,742,743,744,745,749,751,752$, $759,764,771,772,773,774,775,776,778,792,871,872,873,874$, $881,882,883,884,893,951$

5. Human-capital Intensive Products $531,532,533,551,553,554,621,625,628,641,642,672,673,674$, $675,676,677,678,679,691,692,693,694,695,696,697,699,761$, $762,763,781,782,783,784,785$

6. Others $911,931,961,971,999$

Source: the Empirical Trade Analysis (ETA), http://people.few.eur.nl/vanmarrewijk/eta/ 